\title{
Technology Innovation and Engineering' Education and Entrepreneurship (TIEE) in Engineering Schools: Novel Model for Elevating National Knowledge Based Economy and Socio-Economic Sustainable Development
}

\author{
Mahmoud Abdulwahed \\ Founding Head of Technology Innovation \& Engineering Education (TIEE), Qatar University, P.O. Box 2713, \\ Doha, Qatar; m.abdulwahed@qu.edu.qa; Tel.: +974-4403-4109
}

Academic Editor: Muhammad Khurram Khan

Received: 2 December 2016; Accepted: 16 January 2017; Published: 25 January 2017

\begin{abstract}
The Technology Innovation and Engineering Education (TIEE) is a proposed Unit/Center/Department concept model inside a college of engineering. The TIEE concept has been developed in particular taking in consideration the Gulf Cooperation Council (GCC) and/or Qatar contextual needs and National Vision in the transformation into a Knowledge Based Economy (KBE). The main purpose of such structure is to enable engineering colleges to better respond to these emerging needs of the GCC countries. In this paper, the concept of TIEE is provisioned as an abstract example of organizational structure development for other engineering education institutions that aim to play a key role in innovation and sustainable socio-economic development. The concept is derived from similar global examples and contextualized regionally; it is generic and can be deployed elsewhere with slight modifications. The TIEE concept is in particular vital for engineering institutions in the Middle East and North Africa as a vehicle for economic and technological development. The paper outlines the organizational structure of TIEE, together with its various programs and activities for implementing its stated vision, mission, and strategic objectives. Within this context, the paper also provides a thorough account on advances in engineering innovation, education, scholarship of engineering education, and developments of similar entities.
\end{abstract}

Keywords: sustainability; innovation; entrepreneurship; engineering education; organizational development; knowledge based economy; technology; TIEE; sustainable development

\section{Introduction}

\subsection{Engineering, Technology Innovation, and Design}

Engineering in particular and other relevant STEM (Science, Technology, Engineering and Mathematics) fields in general are the most critical sciences for a nation to consider while seeking or maintaining a knowledge based economy status [1-4]. Singapore is one of the very few Knowledge Based Economies (KBE) that has programmed clear innovation and design schemes, and is known for its higher education technical institutions focusing on innovation and design. Recently, a state of the art Singapore University of Technology and Design (SUTD) was established in collaboration with Massachusetts Institute of Technology (MIT). The new University is the latest investment of Singapore government that focuses on developing high quality engineering education driven by multidisciplinary technological innovation and design. The Singaporean government philosophy of focus on technology innovation and design has led to higher value outcomes and GDP growth comparing with similar KBE countries. It has also led to higher growth in engineering publications [5]. 


\subsection{Engineering and Technology Education}

Investment in research in engineering education has been considered a highly strategic national priority in the US in the last few years as a way of maintaining the global competitiveness of the American knowledge based economy. President Obama addressed changing policies to make STEM education a national priority [6]. The engineering curriculum of the 20th century is no longer sufficient to address the engineering challenges of the 21st century. Certain engineering competencies such as problem solving, design, and analytical thinking has become essential, even for those who study and work in non-engineering disciplines [6]. Engineering/STEM graduates are not only demanded for technical and scientific careers, but they have also started to play essential roles in non-traditional fields such as business, finance, management, policy, social studies, etc. It is argued that the definition of engineering should be expanded to cover the emerging trends and roles of modern and future engineering [7].

Technology innovation and design has recently been fostered in novel engineering curricular and educational models as a vehicle to integrate foundational, science, technical, and socio-economic aspects associated with engineering and engineering learning, producing a meaningful product/service oriented manner. Innovation and design have been introduced in first year engineering programs, and in multidisciplinary activities/courses/degrees in novel engineering curricular and education models; see for instance models at Purdue University. Our experience at the College of engineering at Qatar University during the past 3-5 years have shown that deployment of multidisciplinary complex design projects (e.g., the Shell Eco-Marathon car design) has led to transformative impact on engineering students conceptual understanding and integration of learning theories as well as leadership and soft skills development. In addition, our experience in the College of engineering (CENG) at Qatar University has shown that deployment of authentic engineering design in K-12 outreach programs such as the car assembly and design in the Life is Engineering Program have led to significant improvement in high school students attitudes towards engineering, as well as the development of 21st century soft skills [8].

\subsection{Engineering Education Research}

It is believed that advancing innovations in technical engineering requires robust and systematic research in engineering education [9-14]. It is estimated several billions USD of extra funds for STEM education, research and development have been invested in the US in 2009 [15]. Research into engineering education, whether in Higher or K-12 education, is essential to design a modern curriculum, to deliver a competent engineering teaching and learning experience, and to tackle issues faced in the professional settings of the workplace $[3,15]$. There has been growing research evidence that followed methods in teaching and learning of engineering are becoming obsolete and do not meet the requirements of future engineering graduates [16]. On the other hand, recent research on utilizing modern constructivist methods in engineering/STEM education has shown positive outcomes [17-19]. Increasing complexity and interdisciplinarity of the engineering profession requires equipping engineering graduates with a set of non-technical skills such as communication, decision making, management, leadership, emotional intelligence, cultural awareness, and social ethics. A literature review of skills outcomes of engineering degrees in the US, Europe, and Asia Pacific showed that students lack in these soft skills [20-22].

Many American reports and researchers have addressed the importance of investing in engineering education research (EER) to enhance the US competitiveness globally. Lohmann and de Graaff state the following: "Just as engineering excellence depends critically on engineering research and development, excellence in engineering education depends critically on research and development in engineering education" [23].

In recognition of its strategic importance for sustaining a knowledge based economy and maintaining the US global competitiveness, steep escalation in the funding of research projects in engineering education in the US can be noticed since 2007. Triggered by the huge American investment 
and by pressing national needs, attention on research on engineering education is rapidly increasing in many countries worldwide, such as Malaysia, India, Mexico, Europe, Taiwan, etc. [12].

\section{Engineering Education Research and the Learning Sciences}

\subsection{The Emergence of Research in Engineering Education}

Engineering education research is an emergent multidisciplinary arena of research, crossing over different fields. In particular, pedagogy, psychology and social sciences research methods are essential in informing research in engineering education $[7,12]$. Other fields that have been identified to have impact on EER are: sociology, ethnic and gender studies, international relations and other relevant STEM education research areas [14]. EER has been historically limited in quantity and quality because of many factors. For instance, conducting rigorous EER requires knowledge of theories and research methods that reside outside of the engineering domain [24]. Furthermore, engineering educators are mainly immersed in disciplinary technical research as a main focus [24-26]. Nevertheless, it is argued that even if most engineering faculty are not willing to be engaged in EER, all of them should be aware of and apply its findings [27]. Having a subside research track such as engineering education and/or interest in investigating or applying novel pedagogical approaches requires assistance from experts and is normally provided for engineering academics through specialized engineering education centers or units [28]. Indeed, the majority of engineering education researchers are of engineering background [7].

The Steering Committee of the National Engineering Education Research Colloquies [10,29], played a significant role in identifying directions of EER. The committee was composed of about 75 experts in engineering, science, and mathematics education researchers, learning sciences, and practitioners. They met few times in 2005 and 2006 to define focus areas of EER. They highlighted a number of reasons to focus on engineering education, such as globalization and trans-continental enterprising, grand challenges in sustainable engineering, the decline of interest in engineering among school students, maintaining innovation capacity and international competency in a global market, etc. All of these and other reasons require radical change in curriculum and in the way of engineering's teaching and learning [7]. Such a radical change necessitates a systematic and robust research effort on best ways of conducting engineering education $[7,27]$.

\subsection{Scope of Engineering Education Research}

The scope of EER is very wide; more than 38 different categories of EER have been identified in a meta-analysis of about 2000 published journal and conference articles in EER from 2005 to 2008 [30] (Figure 1). This wide spectrum would be expected due to the interdisciplinary nature of the field, the huge issues and problems that need to be tackled in engineering education and in professional practice in the workplace, and due to its recent emerging nature. Some of the EER specific topics to engineering are: motivation towards engineering, retention rates, epistemologies specific to engineering problems, organizational structures, engineering education policies, outreach, industrial linkage, curriculum, instructional methods, recruitment, diversity, retention, engineering academics, assessment, technology entrepreneurship, leadership, etc. The Steering Committee of the National Engineering Education Research Colloquies [10,29], framed five main core interrelated arenas of research in engineering education: (1) Engineering Epistemologies; (2) Engineering Learning Mechanisms; (3) Engineering Learning Systems; (4) Engineering Diversity and Inclusiveness; and (5) Engineering Assessment. These five areas provide framework for the community of researchers in engineering education. The five previous cores are originating from educational and social sciences and have an impact on engineering. However, in our opinion, a sixth dimension "Engineering methods for Design of Effective Pedagogy" could be a core focus of EER as well; this is explained in the next subsection. 


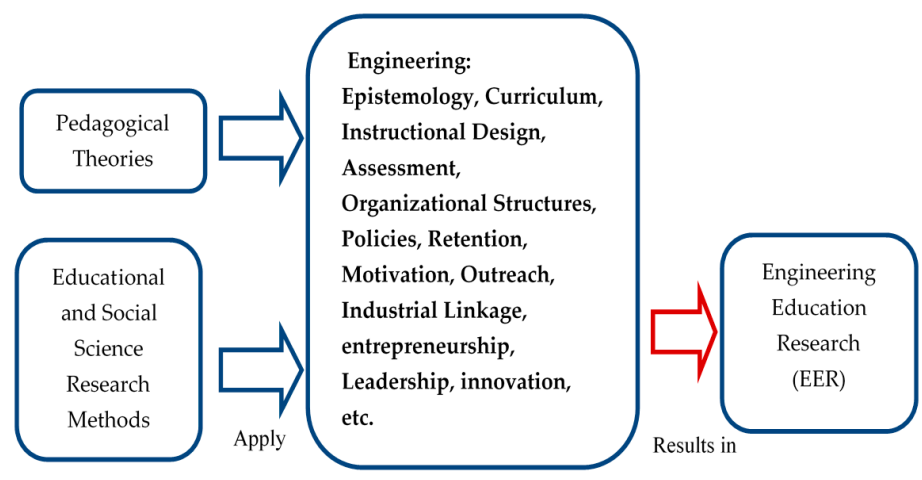

Figure 1. Conceptual diagram of engineering education research (EER). Pedagogical and learning to result educational research methods are applied to engineering curricula, teaching and learning to result in a rigorous EER outcome.

\subsection{Engineering Impact on Educational Sciences}

Educationalists, psychologists, and sociologists could inform the engineering community about theories and methods for improved engineering education as expressed in the previous five cores. However, staffers of engineering background have expertise in technological and analytical tools, e.g., Information and Communication Technologies (ICT) development competencies and engineering design expertise, which would enhance the theory of teaching and learning. Figure 2 shows a conceptual model of the proposed mutual interaction between engineering and education within the community of researchers in engineering education. For instance, a full body of research in instructional and learning design, called the Instructional Systems Development (ISD), has been conceptually inspired by systems engineering [31]. Mathematical control theory and game theory methods have been utilized for analyzing and designing enhanced pedagogical processes [32,33], a data mining methodology (from computer engineering) has been utilized in designing a Research Based Learning (RBL) approach [34]. The potential benefit of applying engineering and mathematical analytical methodologies (apart from the classical quantitative educational research methods) to the learning sciences is highlighted in [12,35]. Developments in ICT (a core engineering competency) are expected to move the hundreds of years old traditional models of teaching and learning into radical forms in the near future. In general, the author classifies the impact of engineering and computing on educational sciences in two major categories:

- $\quad$ Category 1: The development and inclusion of ICT tools in pedagogy.

- Category 2: The utilization of engineering and mathematical methods for analysis and design of learning systems.

While Category 1 is currently a well-established and active arena of Research and Development (R\&D) (e.g., technology enhanced learning, intelligent tutoring systems, e-learning, etc.), some non-statistical based methods in Category 2 are still a quite novel area of research. German institutes were pioneering in developing quantitative statistical approach for quite few years.

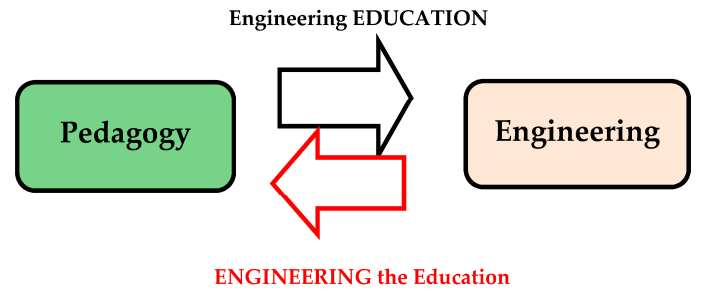

Figure 2. Conceptual model of the interaction between pedagogy and engineering as a framework for the research activities of the proposed Center. 
Having introduced EER, its focus areas and proposed a mutual relationship between engineering and education in the community of researchers on EER, we proceed in the next section with details on international trends in engineering education research and development.

\section{International Trends in Engineering Education Research and Development}

A boom in establishing new engineering education centers, departments, national societies, and research and training programs took place in the US during the last two decades in a trial to maintain the US international innovative competitiveness in science and technology. Australia and Germany come next after the US in terms of interest in engineering education research. There are centers for engineering education support and/or research in the UK, Sweden, South Africa, South Korea and Malaysia. The recent revival and emergence of Engineering Education as a distinct field of science can be largely attributed to the American investment in EER as a strategic national priority, in particular during the last 6-10 years (see. Considerable EER activities are observed elsewhere in the globe with exclusion of the Middle East region.

However, it is worth mentioning that prior to the Anglo-Saxon move into engineering education, the Germans were the first to work (but less publicity was made) in the area of "Ingenieurpädagogik", which literally translates to "Engineering Pedagogy" in English. Pedagogical training for teachers of engineering schools has been provided in Technical University of Dresden, Germany as early as 1850s. The following subsections provide a snapshot on current trends on research and developments in engineering education both at Higher and K-12 Education. Details on centers, departments, under- and post-graduate degrees in engineering education, and the advances in engineering education in K-12 are outlined.

\subsection{Centers on Engineering Education}

University or engineering college's centers and units for engineering education pedagogical support, outreach, research and curricular development are quite common in the US since the 1990s. Engineering education centers have played a crucial role in advancing research in engineering education and in transformation of EER into practice [28]. Examples of these centers are: the Center for Engineering Design Research at Stanford University, Engineering Education Research Center at Washington State University, Center for Engineering Education Research at Michigan State University, Leonhard Center for the Enhancement of Engineering Education at Pennsylvania State University, Center for Engineering and Computing Education at the University of South Carolina, Science and Engineering Education Center at the University of Texas at Dallas, Center for Engineering Education and Outreach at Tufts University, etc.

Outside the US, centers, units and research groups dedicated to engineering education are scattered worldwide, the frequency, however, is much less than in the US; the number is expected to increase rapidly in the next few years. Examples of these centers are: the Engineering Centre for Excellence in Teaching and Learning at Loughborough University, UK, a research group on engineering education at Linköping University, Sweden and the Engineering Learning Unit at the University of Melbourne, Australia. The authors are unaware of any relevant center in the Middle East region.

\subsection{Departments, BSc, MSc, and PhD Degrees in Engineering Education}

The first department in engineering education was established in Technical University of Dresden, Germany in 1951, known in German as "Institut für Ingenieurpädagogik" which translates to "Institute for Engineering Pedagogy"; the first formal PhD thesis in Ingenieurpädagogik was defended few years later [36]. A department like this has been unique in its focus and is one among few that existed until the recent US focus on engineering education. The last few years have witnessed a birth of many independent departments under colleges of engineering in the US, dedicated entirely for research in engineering education and offering structured MSc and $\mathrm{PhD}$ programs (e.g., similar to traditionally existing departments of electrical or mechanical engineering). These departments aimed 
at moving the status in engineering education from isolated research efforts towards active academic communities dedicated for scholarly research work. They aimed also to graduate necessary national capacity in engineering education research through formal MSc and $\mathrm{PhD}$ training. The first of its kind in the US is the School of Engineering Education at Purdue University which was established in 2004 (under college of engineering). Other examples are the Department of Engineering Education (since 2004) at Virginia Tech; the Department of Engineering and Technology Education at Utah State University (since 2005); etc., all under colleges of engineering. BSc degrees in engineering with minor or major on engineering education are offered at California and Colorado State Universities. Due to the strategic nature of their training, graduates of $\mathrm{PhD}$ programs in engineering education seem to be highly demanded in the US for tenure track positions and/or for management positions in education/training in academia and industry [12]. In a recent case, a half way PhD student in engineering education at Virginia Tech got a tenure faculty position (Eng. Ed. Dep. Virg. Tech., 2011).

By actively joining the recent international movement in interest in engineering education, the Germans aimed to revive their early contributing heritage of Dresden (IGIP-REGIONALTAGUNG, 2011). Currently, BSc/BA and/or MSc/MA programs in Ingenieurpädagogik are offered at many German Universities, including Esslingen University of Applied Sciences, Mannhiem University of Applied Sciences, Friedrich-Alexander University, Heidelberg University of Education, Karlsruhe Institute of Technology, etc. Other parts of the world witness accelerated activities in this domain. Universiti Teknologi Malaysia (UTM) started to offer a structured PhD program in engineering education few years ago. The program houses around $20 \mathrm{PhD}$ students as of May 2010 (UTMEER, 2010). This is probably the largest formal graduate EER program outside the US. Formal PhD programs in Ingenieurpädagogik have existed since 1951 in Germany and since the 1970s in Sovakia, and the Czech Republic [37]. Formal PhD programs in engineering education have recently been initiated in India and Mexico [7], interest is high to initiate such programs in other countries such as Pakistan and Taiwan [12].

Traditionally, prior to the establishment of formal engineering education PhD programs, $\mathrm{PhD}$ theses in engineering education topics were conducted and granted within classical engineering departments. One of the very first of its type can be traced to 1920s [12]. This is still, and will continue to be, a trend in many Universities worldwide [12]. It is estimated that only few hundreds of $\mathrm{PhD}$ dissertations have had a focus on engineering education in the period from 1841 till 2008 [38], and majority were granted by classical engineering departments. The number of granted PhDs in engineering education is expected to accelerate rapidly in the next few years as a result of increasing international interest in the field and the establishment of more dedicated departments and centers for this field. The authors are unaware of any department or structured BSc, MSc, and PhD programs dedicated in engineering education in the Middle East.

\subsection{National, Regional and International Societies in Engineering Education}

Apart from University units, centers, and departments, there are independent US centers and societies for engineering education operate on a nationwide level. Some of their main tasks are the production of necessary policies and recommendations for advancing engineering and STEM education as well as conducting EER. Examples include the American Society for Engineering Education, Center for Advancement in Engineering Education, the National Center for Engineering and Technology Education, the Center for Advancement of Scholarship on Engineering Education. Engineering Education Research divisions and groups exist in national societies on engineering education, e.g., in the American Society of Engineering Education (Since 1971), in the Australian Association of Engineering Education (Since 2008), and in the European Society for Engineering Education (Since 2008). The authors are unaware of any national or regional Middle Eastern society dedicated for engineering education. 


\subsection{Engineering Education at K-12 Level}

Implementations of varied forms of engineering education at K-12 level have been carried out mainly in the US and can be traced to the early 1990s. It is estimated that more than six million $\mathrm{K}-12$ students in the US have been exposed to formal engineering education in schools and tens of thousands of K-12 teachers have followed relevant professional development sessions [15]. Engineering activities have been used as one of the most effective vehicles for showing the applicability of taught math, physics and chemistry in K-12 education. There has been growing evidence that incorporating engineering education at K-12 level has a positive impact on stimulating interest and improving learning of science and mathematics subjects [15]. Furthermore, since engineering applications are quite tangible and depend highly on science and math, such approach normally attracts young students in K-12 towards a career in a STEM subject [39]. Engineering could enhance the attainment of learning outcomes of science and mathematics subjects in K-12 curriculum [4]. Regardless of whether students choose to pursue a technical or non-technical study or career after high school, using engineering in $\mathrm{K}-12$ education is a way of developing essential skills for 21st century careers such as problem solving, creativity, leadership, teamwork, organization and management skills, etc. [4].

Structured engineering education in K-12 seems to be less common practice outside the US; however, a new K10-12 program, called Diploma, has been implemented in the UK recently (since 2009). In this program, students specialize and follow constructivist hands-on training in tracks similar to those followed in higher education; there are seven tracks, and one is engineering. Australian reforms of $\mathrm{K}-12$ education in the last few years have witnessed the introduction of some formal engineering training into K-12 curriculum. Generally, in Europe, technology (often technology and design) is used rather than engineering to broaden the content and is a compulsory subject in many countries for K-12, Switzerland being an exception. In Sweden, a K10-12 engineering program reemerged in 2014 (it had been absent since 1994). We expect that K-12 education in the Gulf Cooperation Council (GCC) and Qatar is in need of more formal and informal integration of engineering, computing and technology in its curriculum.

\section{Scoping to the GCC States and Qatar and the Emerging Needs of Sustainable Development}

In the GCC and State of Qatar, engineers continue to play important roles in the majority of industrial and governmental sectors. Horizontal and vertical expansion in infrastructure, mega projects, and several GCC countries visions in transforming into a knowledge based economy by 2030, makes it urgent to focus on engineering/STEM education. We think that the need to take urgent and proactive actions in engineering education in the GCC, informed by systematic contextual research, to respond for contextual current and future needs is among the most pressing demands worldwide.

In particular, with the recent decline of oil and gas prices since 2014, GCC countries have been looking more seriously into diversification of their economic resources, with particular focus on technology, innovation, and knowledge based economy streamlines. GCC engineering and technology manpower play a cornerstone in this diversification process. Several implications are expected on engineering and technology man power in terms of quantity and quality. For instance, there will be need for more numbers of engineering and technology graduates, and hence increasing the pipeline with interventions starting from K-12 becomes essential. In terms of quality, there will be a need for a significant proportional shift from operational engineering functions towards innovation, design, sustainability, R\&D, and commercialization functions. Hence, competencies set required of engineering and technology graduates will need to change significantly. Furthermore, the changes in engineering and technology to cope with innovation and knowledge based economy transformation needs to have several other layers, including but not limited to governmental policy and incentives changes, industry organizational change, workplace engineering training, shifts towards management of innovation, focus on derivatives in oil and gas, higher penetration of digital tools and digital transformation processes, etc. Proper planning and execution of all these changes should be advised by rigorous research that is normally outside the interest and capacity of vertical/technical engineering 
departments (e.g., civil or mechanical engineering). Here comes roles of engineering and technology innovation and education centers or departments that aim to house multidisciplinary expertise in areas such as innovation, design, education, psychology, industrial and systems engineering, policy, sustainability, etc.

\section{Proposal of Organizational Entity in Engineering Schools for Driving Sustainable Development}

\subsection{Sustainable Development Foundations of the Proposed Entity}

In this paper, a proposal of establishing an innovation department/entity in engineering schools to focus on two main pillars of sustainable developments:

- Transformative engineering and technology human talent sustainable development

- Technologies, products, services, innovations, and startups for shaping sustainable socio-economic development

The proposed entity could be a center, a unit, or more comprehensively a multidisciplinary department, and the proposed name is "Technology Innovation and Engineering Education/Entrepreneurship (TIEE)". The role of engineering and technology in sustainable socio-economic development is one of the major focuses in teaching, learning, services, and R\&D of the proposed entity.

\subsection{Drivers of the Proposed Structure}

The proposed restructure is motivated by two main drivers:

(1) Driver 1: Meeting internal, local, and contextual needs:

a. Higher level and more efficient coordination, accountability, management, and sustainable innovation in engineering courses offering (in particular inter- and multidisciplinary offerings).

b. Increased industrial needs of national engineering graduates in the GCC area with further multidisciplinary experience and professional, technical and soft skills.

c. More focus on multidisciplinary technology innovation and design at colleges and schools of engineering as a direct response for the role of engineering in National Visions (e.g., Saudi Vision 2030, and Qatar National Vision 2030) and advancing a knowledge-based economy.

d. Establishing a multidisciplinary engineering department (as opposed to existing traditional disciplinary departments in engineering schools) that provides a natural departmental house for attracting needed and related multidisciplinary engineering expertise faculty that would not normally fit in the culture, disciplinary focus, and professional activities of disciplinary engineering departments.

(2) Driver 2: Catching up with international trends related to internal needs, and forming a driving leading force locally and regionally:

a. Significant emergences in establishing multidisciplinary/general engineering departments with focus on technology innovation, design, first year engineering, general engineering, multidisciplinary programs on undergraduate/postgraduate (UG/PG) levels, engineering education research and practice, etc.

b. Emergence of the Engineering Education Research as an independent wide scope multidisciplinary field scholarship utilized for informing: 
i. Informing Engineering Education Teaching, Learning, Curriculum Innovation, and Practice beyond accreditation agencies requirements, e.g., Accreditation Board for Engineering and Technology (ABET) from US.

ii. Informing Engineering and Engineering Education Policy on Institutional, National, or Regional Levels.

iii. Informing Industry relations, practice, linkage, and engineering profession.

In another dimension of necessity, it can be argued that the engineering curriculum in many developing countries is derived from foreign curriculum taken from the US, Western Europe or Eastern Europe. This could be a useful approach, in particular with the absence or weakness of national institutions that would be able to develop a robust national curriculum. However, a curriculum developed in the West is strongly governed by its history, and industrial, economical and societal needs, which could significantly differ from those of a developing country. Furthermore, the West has reached a rather stable point, while some countries such as Qatar, China, India and Turkey witness a phenomenal development; a curriculum of a highly adaptive nature could better suite such circumstances [40].

\section{Description of the Proposed Entity}

The new proposed entity will work in integrative manner across engineering departments for driving multidisciplinary technology innovation, design, and engineering education scholarship, research, practice, and K-12 outreach. The focus on engineering education research and practice is with the aim of resulting in sustainable engineering and technology talent development equipped with mindset, skills, knowledge, and competencies to drive sustainable economic growth. The focus on technology innovation, multidisciplinary design, product development, and commercialization is with the aim of positioning engineering and technology at the core of future sustainable economic development of GCC countries.

The proposed new department will be responsible for the general and multidisciplinary engineering program/offerings, and it will gradually tab in related multidisciplinary engineering faculty expertise to teach general engineering offerings. The latter will become an academic integrative platform. The attracted faculty will form a driving core force for brining multidisciplinary technology innovation, design, entrepreneurship, engineering education practice and scholarship, and sustainable development into higher levels at GCC engineering schools.

\subsection{Proposed Name}

The proposed name of the entity is Technology Innovation and Engineering Education (TIEE). This provides two dimensions of scope: (1) technological innovation and entrepreneurship and its related techno-socio-economic aspects; and (2) educational innovation (with particular focus here on engineering and technology education).

\subsection{Mission, Vision, and Strategic Objectives}

\subsubsection{Mission}

To offer competent multidisciplinary and general engineering education, and to support contextually oriented technology innovation, design, entrepreneurship, and education practice and research in integrative manner with disciplinary engineering departments and other interrelated non-engineering disciplines. 


\subsubsection{Vision}

To become a leading regional model and development force in the practice and scholarship of technology innovation, entrepreneurship, and engineering education.

\subsubsection{Strategic Objectives}

Objective 1-Deliver Competent Multidisciplinary General Engineering Education: Provision and coordinate innovative multidisciplinary and competent general engineering offerings in the college of engineering on Foundational, UG and PG levels considering disciplinary departments needs and contextual market demands.

Objective 2-Elevate Multidisciplinary Technology Innovation, Design, and Entrepreneurship: Service CENG disciplinary departments in driving multidisciplinary technology innovation, design, and entrepreneurship practices, in connection with contextual/local industrial, societal, and economical needs for sustainable socio-economic development.

Objective 3-Emphasize Industrial/Professional Experience, Leadership, and Social Responsibility of Engineering: Offer an integrative cross-departments organizational, and academic offerings platform for emphasizing multidisciplinary professional engineering experience and social responsibility of engineering graduates.

Objective 4-Advance Sustainable Technology Innovation and Engineering Education Research, Practice, and K-12 Outreach: Support and drive novel innovations, engineering education research, scholarship, practice, and K-12 outreach nationally and regionally.

The mission and objectives will be implemented through a number programs, services, and research activities. Table 1 shows a mapping between the entity activities and its objectives. The required multidisciplinary engineering faculty expertise to lead these activities is shown in Table 2 .

Table 1. Mapping between objectives of the new entity and means of implementations (academic programs, services, and research).

\begin{tabular}{|c|c|c|c|c|c|}
\hline & Department Purposes/Objectives & Obj. 1 & Obj. 2 & Obj. 3 & Obj. 4 \\
\hline \multirow{5}{*}{$\begin{array}{l}\text { Academic } \\
\text { Programs }\end{array}$} & First Year General Engineering Program (FY-GENG) & $\mathrm{X}$ & $\mathrm{X}$ & $\mathrm{X}$ & $\mathrm{X}$ \\
\hline & $\begin{array}{l}\text { Technology Innovation, Design, and Entrepreneurship } \\
\text { General Engineering Program (TIDE-GENG) }\end{array}$ & $x$ & $x$ & $x$ & $x$ \\
\hline & $\begin{array}{l}\text { Minors/Degrees in Engineering Leadership, in } \\
\text { Engineering Education, in Engineering } \\
\text { Entrepreneurship (UG/PG) }\end{array}$ & $x$ & & $x$ & $x$ \\
\hline & $\begin{array}{l}\text { Minor/Major/Degree in Tech. Innovation and } \\
\text { Design (UG/PG) }\end{array}$ & $x$ & $x$ & $x$ & $x$ \\
\hline & $\begin{array}{l}\text { Minor/Major/Degree in Technology and Sustainable } \\
\text { Development (UG/PG) }\end{array}$ & $x$ & $x$ & $x$ & $x$ \\
\hline \multirow{3}{*}{ Services } & Rapid Prototyping and Incubation Hub & & & $x$ & $\mathrm{X}$ \\
\hline & Engineering Learning Hub & & & $x$ & $x$ \\
\hline & $\begin{array}{l}\text { Professional Development in Engineering Education } \\
\text { Research and Practice }\end{array}$ & & & & $x$ \\
\hline \multirow[t]{2}{*}{ Research } & $\begin{array}{l}\text { Technology Innovation, Design, and Entrepreneurship } \\
\text { Research Group }\end{array}$ & $x$ & $x$ & $x$ & $x$ \\
\hline & Engineering Education Research Group & $X$ & $x$ & $X$ & $X$ \\
\hline
\end{tabular}


Table 2. Multidisciplinary engineering faculty expertise to be attracted.

\begin{tabular}{|c|c|c|c|c|c|}
\hline Expertise & $\begin{array}{c}\text { Background } \\
\text { BSc }\end{array}$ & $\begin{array}{l}\text { Background } \\
\text { MSc/PhD }\end{array}$ & $\begin{array}{l}\text { Example of } \\
\text { Graduating } \\
\text { Schools }\end{array}$ & $\begin{array}{l}\text { Name of } \\
\text { Graduating } \\
\text { Program }\end{array}$ & $\begin{array}{l}\text { Teachings } \\
\text { Mapping in } \\
\text { the TIEE }\end{array}$ \\
\hline $\begin{array}{l}\text { Technology } \\
\text { Innovation, Design, } \\
\text { Entrepreneurship, and } \\
\text { Sustainable } \\
\text { Development (with } \\
\text { industrial experience) }\end{array}$ & $\begin{array}{l}\text { Mech., Elect., } \\
\text { Civ., Design., } \\
\text { Systems., }\end{array}$ & $\begin{array}{l}\text { Technology } \\
\text { Innovation, } \\
\text { Engineering } \\
\text { Design }\end{array}$ & $\begin{array}{l}\text { Purdue } \\
\text { University, } \\
\text { Penn. State } \\
\text { University, } \\
\text { Imperial } \\
\text { College }\end{array}$ & $\begin{array}{l}\text { Engineering Design, } \\
\text { Technology } \\
\text { Innovation and } \\
\text { Design, Technology } \\
\text { Entrepreneurship, } \\
\text { Systems Engineering } \\
\text { Design }\end{array}$ & TIDE-GENG \\
\hline $\begin{array}{l}\text { Engineering Education } \\
\text { (including Technology } \\
\text { Enhanced Engineering } \\
\text { Learning) }\end{array}$ & $\begin{array}{l}\text { Engineering } \\
\text { (Any), } \\
\text { Computer } \\
\text { Science } \\
\text { (for TEEL), }\end{array}$ & $\begin{array}{l}\text { Engineering } \\
\text { Education }\end{array}$ & $\begin{array}{l}\text { Purdue } \\
\text { University, } \\
\text { Virginia Tech., } \\
\text { Utah State } \\
\text { University }\end{array}$ & $\begin{array}{l}\text { Engineering } \\
\text { Education; } \\
\text { Technology } \\
\text { Enhanced Learning }\end{array}$ & $\begin{array}{l}\text { FY-GENG; } \\
\text { TIDE-GENG }\end{array}$ \\
\hline
\end{tabular}

TIEE: Technology Innovation and Engineering Education; TIDE-GENG: Technology Innovation, Design, and Entrepreneurship General Engineering Program; TEEL: Technology Enhanced Engineering Learning; FY-GENG: First Year General Engineering Program.

\subsubsection{Academic Programs}

First Year General Engineering Program (FY-GENG): The FY-GENG will work on introducing common first year engineering experience among engineering students through revamping existing courses and internal CENG policies in collaboration with college of engineering departments, and through introducing hands-on and engineering professional activities focusing on design, creativity and innovation; connection with professional experience in field; and early on various engineering disciplines tasters. The FY-GENG will work closely as interface and needs alignments of first-year math and science courses.

Technology Innovation, Design, and Entrepreneurship General Engineering Program (TIDE-GENG): This is structured design and entrepreneurship oriented program and deployed cross-curricular in both vertical and horizontal levels working on instilling multidisciplinary innovation, design, and commercialization:

(1) Foundational design Horizontally via the FY-GENG

(2) Vertically through the curriculum utilizing:

a. General Engineering Course in level 200 in Systems, Design, and Entrepreneurship

b. Course Small design Projects in Existing General Engineering Courses in levels 200 and 300

(3) In-Depth and Complex Design Horizontally via Multidisciplinary Senior Design Project at Level 400

An example list of normally existing general engineering courses in UG and PG level in colleges of engineering can be found in Appendix A. Restructured, and built upon these courses for developing the FY-GENG, TIDE-GENG and other multidisciplinary offerings becomes a natural step in the development of TIEE department concept. Figure A1 shows example of positioning of the horizontal (FY-GENG) and vertical (TIDE-GENG) programs within the technical disciplinary engineering programs in a college of engineering.

Other Opportunities for Academic Offerings: The proposed structure enable developing, managing, and/or coordinating with other departments new relevant concentrations, minors or programs on Undergraduate (UG) or Postgraduate (PG) level, for example:

(1) Concentration/Minor in Engineering Leadership (BSc level): Could be in particular useful for Qatari engineering graduates who would progress into leadership positions relatively quick in their career. 
(2) Minor or Degree in Technology Innovation and Design (BSc level): Suitable for disciplinary graduates with professional career plans in systems integration, design and development.

(3) Minor in Engineering Education (MSc/PhD): Suitable for graduates with academic engineering career plans.

(4) Minor in Engineering Entrepreneurship (BSc/MSc/PhD): Suitable for graduates with own business and startups career plans.

(5) Minor/Major/Degree in Technology Innovation and Design (MSc): Suitable for graduates with professional engineering career plans.

(6) Minor/Major/Degree in Technology and Sustainable Development (BSc/MSc/PhD): Suitable for graduates who will work in suitability and policy related careers in government and industry, as well as, for sustainability academia career tracks.

\subsubsection{Services}

Professional Development in Engineering Education Research and Practice (PD EERP): The department will frequently provide professional development sessions, workshops, and training and certification programs for disciplinary engineering faculty members from other engineering departments or other national/regional engineering institutions. Such professional development will include demonstrations of novel methods in engineering teaching and learning, and approaches and methods for conducting engineering education research.

Engineering Learning Hubs (ELH): These are specific tailored learning spaces and services to offer learning support for struggling and at-risk engineering students.

\subsubsection{Research and Development}

The new department will tab in and attract gradually multidisciplinary engineering faculty expertise in: (1) Technology Innovation and Design; and (2) Engineering Education. The establishment of the department is expected to emerge research and development activities in two main new applied multidisciplinary areas connected directly with internal needs to the college, and local socio-economical needs.

Technology Innovation, Design, and Entrepreneurship (TIDE) Group: Developments in this group are mainly of applied nature focusing on fostering technological innovation and design (using multidisciplinary engineering approach) for resolving contextual industrial and/or socio-economical needs. The group, with its multidisciplinary expertise in design and entrepreneurship, will work on technology and engineering entrepreneurship for brining developed technical products/services into commercial realization.

Technology, Policy, and Socio-Economic Sustainable Development (SD) Group: This group will work on studies and research projects mainly in domains of science and technology policy, and the role of innovation, science, engineering, and technology in socio-economic development. Further focus will be paid on science, engineering, and technology solutions for sustainable development in the GCC area. Research on deploying sustainable development in existing government and industry organizations in the GCC is a major focus as well.

Engineering Education Research (EER) Group: Faculty and staff at the department will conduct applied research in engineering education and learning. Findings of the research will be utilized to scale up best tested approaches. In addition, faculty and staff of the department will support and collaborate with other faculty in other engineering departments who are interested in conducting engineering education research. Other areas of developments focus will be related to Technology Enhanced Engineering Learning (TEEL). Examples of areas of focus in TEEL are flipped classroom, formative assessment with TEEL, Massive Open Online Courses (MOOCS), remote and virtual labs, e-learning, learning technologies, mobile learning, and intelligent tutoring systems, instructional design, etc. It is worth mentioning that such digitally enabled planned streams are of both a practical and R\&D scope, which are both interchangeably feeding back into each other. For instance, applications 
of ICT into engineering education and learning and teaching practice will be informed by R\&D findings, and this application will feedback data and more in-depth insight into next directions of such digitally enabled learning and teaching in engineering.

\subsection{Needs for the New Entity}

\subsubsection{Organizational Needs}

Its main organizational needs are:

(1) Offering an organizational house for attracting multidisciplinary (general) engineering faculty (in engineering education, technology innovation, design, and entrepreneurship) that could be of a more fit for teaching and learning of general engineering offerings than disciplinary engineering faculty housed in the disciplinary departments.

(2) Enhance of general engineering courses offerings and sustainable innovation via direct provision, accountability, reporting, revision, and management of the general engineering program and courses that are normally provisioned by several departments at once.

(3) Support significant emergence of state of the art practice and scholarship of technology innovation and engineering education in the college of engineering departments via attracting a core group of related multidisciplinary engineering faculty expertise as a driving force.

\subsubsection{Added Value of the New Entity and How It Will Complement and Support Other Existing}

Departments in the College of Engineering

- Better prepared students before entering into major after finishing the first year engineering program.

- Further assistance in ABET accreditation for criteria focusing on multidisciplinary design and soft skills development.

- Faculty professional development, consultation, and collaborative research in multidisciplinary technology innovation, design, and engineering education.

- A platform for equipping students from disciplinary with experiential hands-on practical experience linked with multidisciplinary design for real industrial and socio-economic issues, and is informed by proved pedagogy and engineering education research.

- Positioning a college of engineering as leading institute in the area, in the emerging field of engineering education research.

- Further compliance with local industry needs and higher level satisfaction of college of engineering graduate students.

- Support of the college disciplinary departments in their K-12 outreach and initiating new College outreach activities.

\subsection{Expected Impact and Measures of Success}

\subsubsection{Expected Impact on Instructional and Research Activities}

The proposed department is expected to have significant impact on instructional and research activities:

(1) Opening new area of Scholarly Disseminations technology innovation and engineering education in form of high quality journal articles, books and book chapters, and conference papers.

(2) Provisioning of Professional Development Educational and Training Programs in engineering education.

(3) Relatively low cost research (costs are mainly associated with human resources salaries, no need for expensive experimental hardware and labs for instance). On the other hand, outcomes of research are of significant impact on engineering capacity development. 
(4) Fostering of further linkage between academia and industry/society in the GCC or Qatar.

\subsubsection{Potential Measures of Success}

The following are some examples of the measures of success:

(1) Increase in number of new innovations in curriculum development and engineering education provisioning in other departments in the College of Engineering as outcome of collaboration with faculty of the new department.

(2) Increase in number of male national citizens enrolled and in engineering as outcome of new K-12 engineering outreach activities.

(3) Enhancement of retention rates in engineering, in particular with minority segments (least retention group).

(4) Satisfaction level of College of Engineering departments and programs with incoming students after completing the First Year Engineering Program.

(5) Satisfaction level of engineering experience of College Engineering students, in particular in issues related to multidisciplinary design and general engineering courses experience.

(6) Increase of number of multidisciplinary design projects with direct link to local/contextual industrial or socio-economic needs.

(7) Number and amount of newly attracted funds from National Research Funds and local industries in areas related to technology innovation and engineering education.

(8) Number of joint scholarly publications between the new department faculty and other faculty departments and research centers faculty and staff.

(9) Number of Faculty professional development provisioned by the new department for other faculty, and level of engagement.

(10) Number of new technology startups and commercialization from students and faculty of the school of engineering.

\section{Challenges in Realization of TIEE Concept Relative to the Current Engineering Schools System, Strategies for Implementation, and Envisioned Benefits}

\subsection{Challenges}

Our experience shows significant challenges in realization of such TIEE entity in a GCC or Middle Eastern context in which we have pushed for implementation. First, engineering academic mindset in the GCC/MENA (as in several other regions) is significantly technically and vertically focused, while the proposed TIEE concept is more of a multidisciplinary and horizontal nature that touches on several non-engineering or non-technical fields (e.g., business, sustainability, education, social sciences, etc.); hence there are significant conceptual differences in understanding the purpose, nature, and needs of such entity among engineering academic community and accordingly getting the needed support.

Second, innovation adoption normally follows an $S$ curve [41], in which it is very slow for a period, which is normally long in low innovation adoption environments. The higher level the innovation, the slower adoption is. TIEE concept is to a significant extent a high level organizational innovation, or even could be considered as a disruptive innovation. Christiansen and Overdorf [42] suggest that for disruptive organizational change, a spin off organizational structure should be considered when the processes and values fit of the new innovation is poor within the existing organizational structure. TIEE values and processes are significantly different from those of technical and vertical engineering departments in classical engineering schools, and hence spinning off TIEE in a separate organizational structure provides a significant methodological approach for growing its planned functions. Figure 3 shows the space of possibilities for organizational innovation development. States A, B, C, and D represent various states of innovation fit with values and processes of an organization. For instance, taking a college of engineering as an organizational example, a development of a 
minor/major in control systems engineering within an electrical engineering program could have a good fit with values of electrical engineering department and program development processes, hence it could be an example of state A. For State B, a development of joint degree between college of engineering and college of business (e.g., on technology innovation and management) may have a good fit with college of engineering values, but low fit with its processes (e.g., accreditation necessities from business side, cross-college collaboration, etc.). State $C$ may represent establishing an R\&D technical center within the college. Such center main function is technical research and development, which fit well with college of engineering processes (e.g., R\&D is one of the major functions of engineering faculty), however, translating $R \& D$ outcomes into products and revenue generating startups would require business mindset and core competencies and values that are normally lacking within the engineering school community, hence commercialization normally facilitated by a spinout organization (e.g., Technology Transfer Office, Accelerators, etc.). The TIEE department may represent a case in State $C$, as both processes and values are quite different from those classical ones of technical departments and conventional schools of engineering (e.g., multidisciplinary focus, faculty expertise, business and commercialization focus, type of education and programs, etc.).

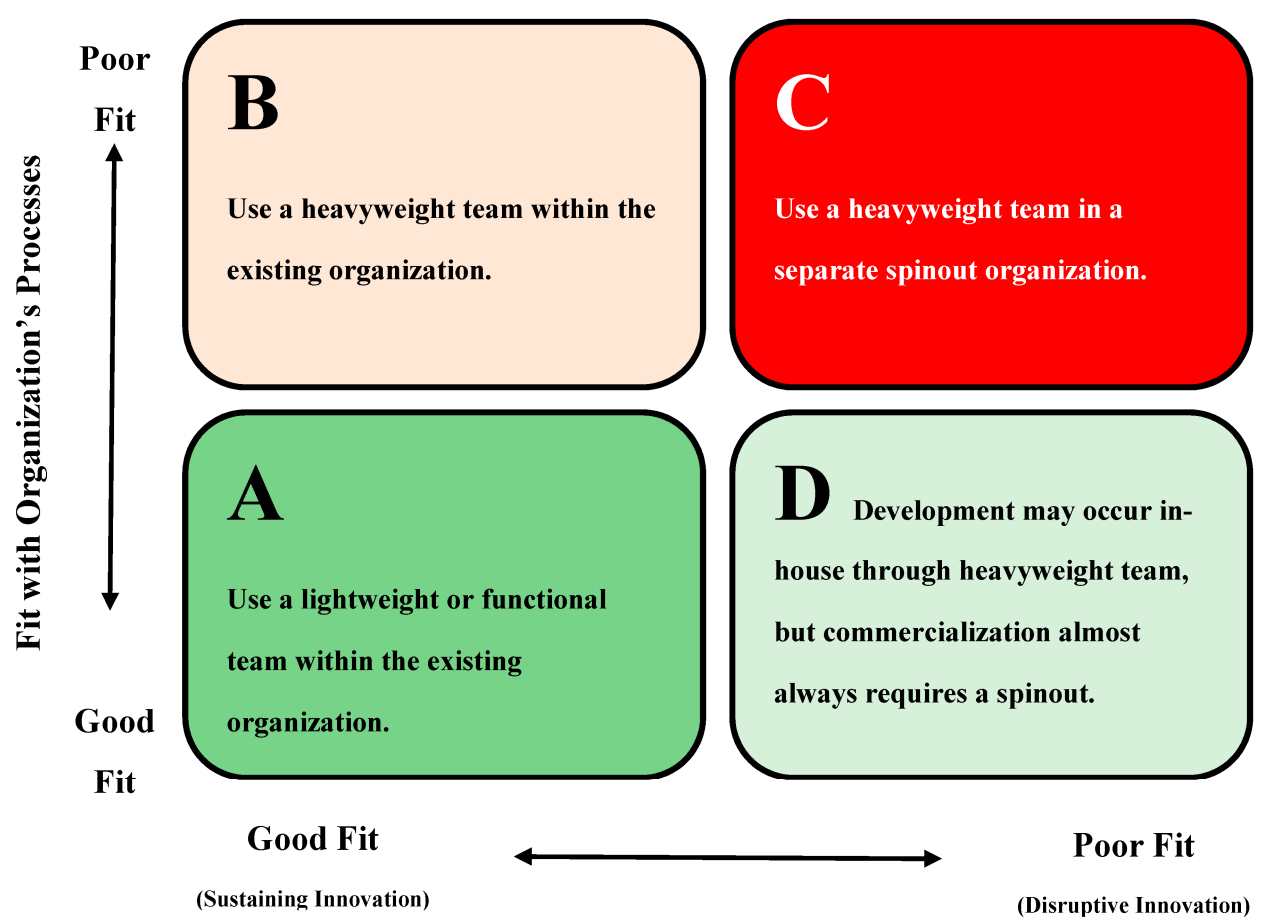

Fit with Organization's Values

Figure 3. Organizational Design for Disruptive Innovation [42].

Third, in spinning off such TIEE entity comes internal politics of the organization (here an engineering school). For the TIEE Department particular case, it is interrelated literally with almost every department and office in an engineering school due to its horizontal and multidisciplinary nature; hence, the level of internal politics is significantly high.

Fourth, and probably the most important challenge, is the senior leadership driver on the level of engineering school to understand, adopt, and push such organizational innovation, and the scarcity of TIEE related multidisciplinary competencies among the engineering faculty community. For proper realization, an engineering school will need: (1) its senior leadership's political and resources support (sometimes beyond the engineering level, e.g., on the executive University level); and (2) a core collaborative driving team with the relevant TIEE competencies to initiate the development, brings concepts into tangible programs, courses, practices, impacts, etc., and diffuse the latter across the 
school of engineering. Core TIEE competencies are relatively scarce globally, and highly scarce in the Middle East and GCC area.

\subsection{Strategies for Implementation and Challenges Minimization}

Several strategies can be devised to minimize the impact of the several challenges mentioned above, such as:

- For recruiting the core multidisciplinary faculty team, develop a gradual staffing plan over 4-5 years through re-allocation of upcoming opening faculty positions in the college of engineering from various departments to the new TIEE department (re-allocated to teach General and Multidisciplinary engineering subjects normally taught by various department) on the account of releasing the technical department from teaching general engineering subjects gradually. On a lump sum, this is almost of a zero-cost staffing to the college. In addition, this strategy will allow enough time to search and head hunt for necessary expertise, which is normally scarce.

- Develop a series of TIEE professional development seminars, workshops, as well as structured programs (maybe with certification) to help technical faculty in disciplinary departments to grow their engineering innovation and education competencies and apply it.

- Develop cross-department innovation working group tapping on various interests of existing disciplinary and technical faculty. For instance you may find one or more in each department that would be interested to test and develop active learning teaching methods (e.g., flipped classroom). Group these into one working group and offer them structured professional development and frequent consultancies during the implementation of the innovation approach. As the group competencies grow with time, these becomes agents of innovations diffusion across the various technical departments. Other examples of these cross-department innovation groups are "Learning Technologies", "Multidisciplinary Design", "Innovation and Entrepreneurship", etc. Figure A2 in Appendix B shows an example of an innovation working group on "Flipped Classroom".

- Encourage and support disciplinary and technical faculty to conduct research in engineering education. Several research active engineering faculty are also passionate about teaching and learning and would be interested in taking a bit extra investment on their time spent on testing new engineering education approach to evaluate their impact and disseminate findings. They lack education research methods and proper experimental design. The role TIEE department faculty expertise is to help these champions to take their interest into next stage of implementation. Positive research findings can be disseminated internally through seminars and showcases, leading to encourage other technical faculty to test new engineering education approaches, and probably publish as well.

- Follow an experimental approach in which a new educational innovation is piloted first, evaluated, improved, and then upon satisfactory evaluation findings scaled up across the college. Show data evidence of impact widely across the engineering college community. For instance, Figure A3 in Appendix C shows $20 \%-50 \%$ and $500 \%$ enhancement in learning gains of two different engineering education innovation interventions (see [32,43] for further details).

- Tap in and integrate (within the whole picture of TIEE framework) resources existing in other departments (e.g., labs equipment, workshops, faculty interests and expertise, student leaders, etc.).

- Develop the various programs, courses, labs, activities, etc. of the TIEE department systematically and gradually over a period of $4-5$ years parallel to building the necessary team (externally through recruiting, and internally through developing necessary core competencies in technical engineering faculty of interest). See Figure A4 in Appendix D for an example of a prioritized and gradual implementation plan. 
In addition to the proposed strategies earlier, we recommend developing the TIEE framework in at least two engineering schools (preferably in two different GCC countries) in close collaboration and partnership. The dual approach would help in learning lessons from each other, and could accelerate the emergence of TIEE implementations across the GCC area based on rationalized success in this concept article.

\subsection{Envisioned Benefits}

Despite the previous challenges, expected benefits (or Return in Investment (ROI)) is significant. First, a TIEE Department overall cost is close to minimal as a lump sum cost of engineering school, since such department will be carrying out the teaching of general engineering courses that are normally split across the disciplinary departments. The difference here is that with a TIEE, the competency set of TIEE faculty is multidisciplinary, which you would not normally find in technical departments. The concept here is that with such multidisciplinary competency set, several distributed technical/vertical assets across the engineering schools can be leveraged together into two main sustainable development streams as described earlier in this paper: (1) engineering and technology human capital sustainable development (engineering education research and practice dimension of TIEE); and (2) sustainable economic development (innovation, design, and entrepreneurship dimension of TIEE). These crucial sustainable development dimensions for knowledge based economies are rather poorly addressed in current engineering school systems [40,44], in particular Middle East and North Africa.

\section{Conclusions}

Most of engineering schools in the GCC and the Middle East follow a traditional disciplinary department's structure, with curriculum mainly focused on engineering sciences and theories. In this paper, we propose establishing a multidisciplinary entity in engineering schools with focus on driving the applied side of engineering together with innovation, design, and all the way towards commercialization and entrepreneurship. The other nexus of the proposed entity aims at deploying state of the art practices in engineering education, and foster conducting engineering education research among engineering faculty. The latter activity emphasizes continuous innovation in engineering education delivery and content, as well as utilizing the scientific method for solving educational problems facing the engineering education system in the GCC and the region. The proposed TIEE entity in this paper elevates the role of engineering schools in sustainable engineering and technology human talent development via fostering innovation in engineering education, and also sustainable socio-economic development via fostering technological innovation and entrepreneurship.

Acknowledgments: Feedbacks from several senior leaders, academics, faculty, and students at College of Engineering, Qatar University have contributed to refining the proposed TIEE conceptual framework, this is gratefully acknowledged.

Conflicts of Interest: The author declares no conflict of interest.

Appendix A. Example of General Engineering Offerings that Normally Exist in Colleges of Engineering

\section{GENG Undergraduate Courses:}

(1) GENG 106 Computer Programming;

(2) GENG 107 Engineering Skills and Ethics;

(3) GENG 111 Engineering Graphics;

(4) GENG 200 Probability and Statistics for Engineers;

(5) GENG 201 Electric Circuits I;

(6) GENG 231 Materials Sciences;

(7) GENG 300 Numerical Methods; and

(8) GENG 360 Engineering Economics. 


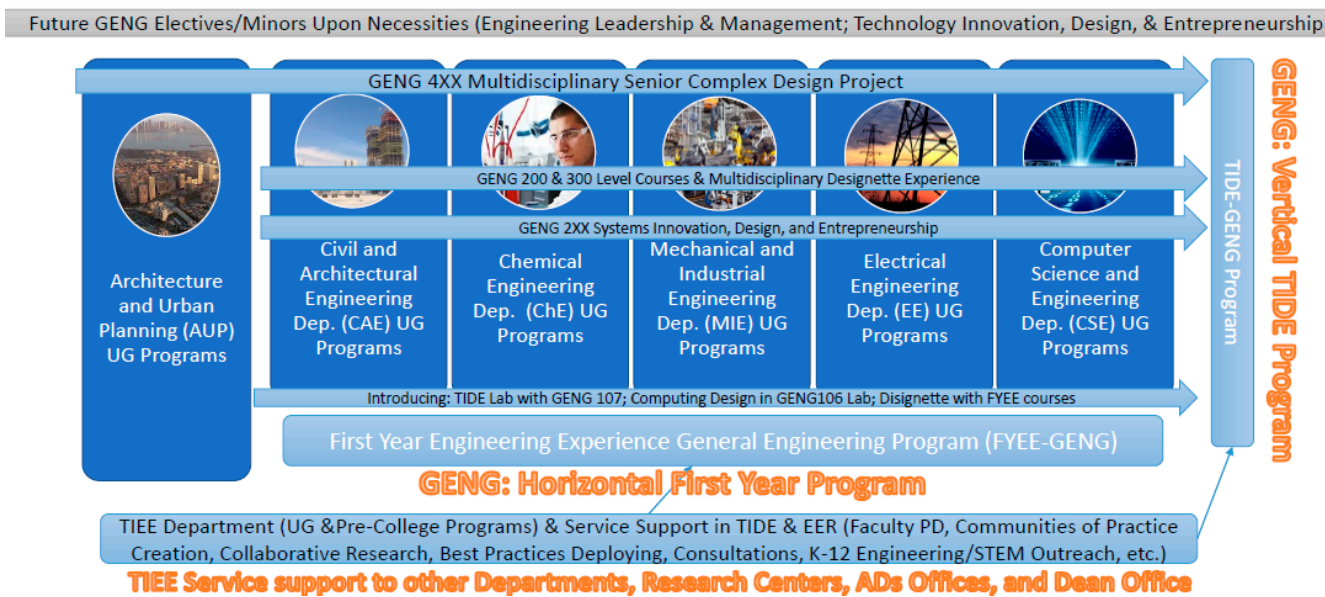

Figure A1. Example of positioning of horizontal and vertical general engineering programs within disciplinary programs curriculum.

\section{GENG Postgraduate Courses:}

(1) GENG 602/DENG 602 Applied Research Methodologies;

(2) GENG 603/DENG 603 Advanced Numerical Analysis;

(3) GENG 604 Project Management;

(4) GENG 605/DENG 621 Applied Statistics Analysis;

(5) GENG 606/DENG 621 Graduate Seminar; and

(6) DENG 624 Innovation and Technology Management.

\section{Appendix B. Example of Innovation Working Group (Focused on Flipped Classroom in This Case)}

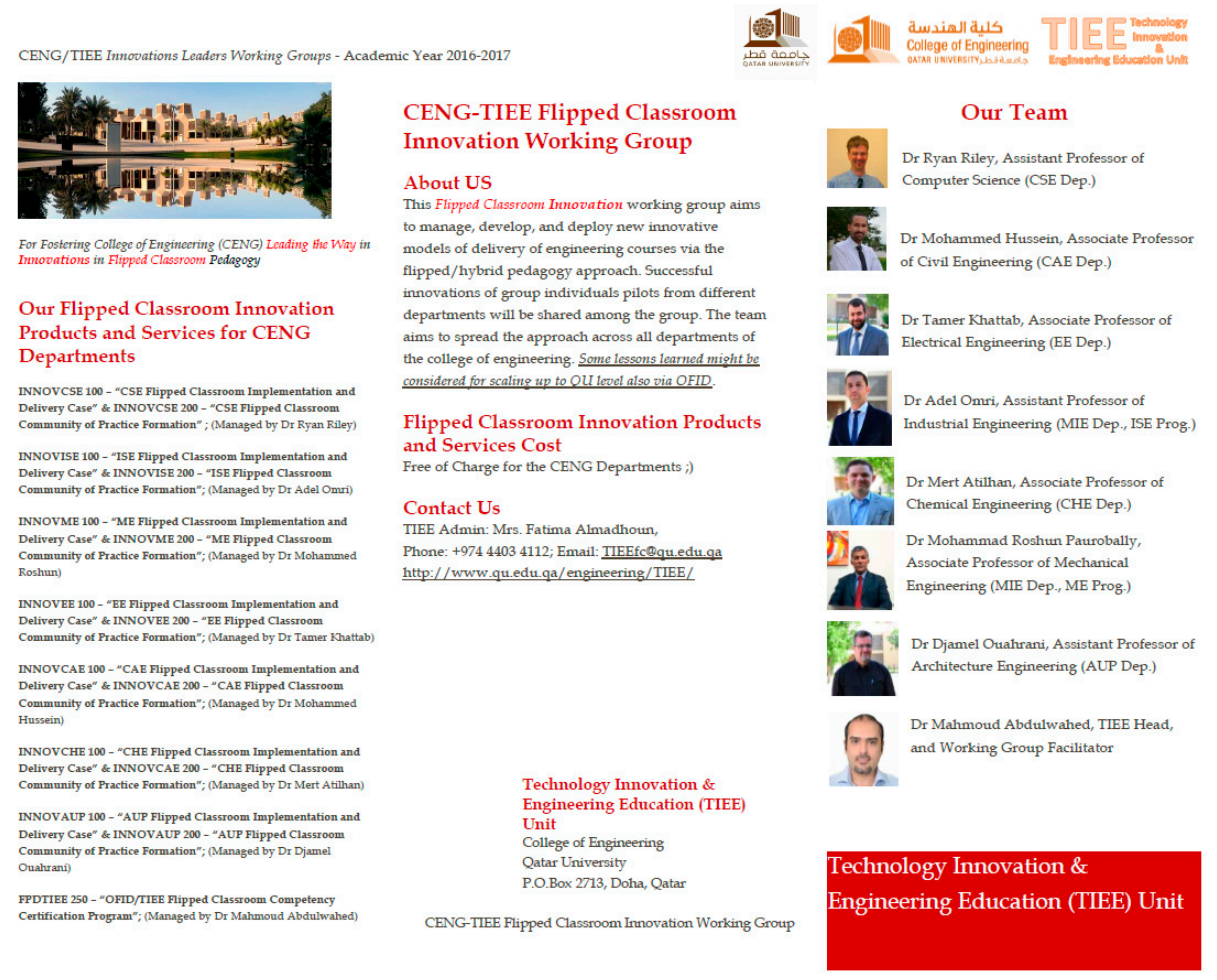

Figure A2. Flipped classroom innovation working group membered by disciplinary faculty of interest from various disciplinary departments. 


\section{Appendix C. Examples of Engineering Education Innovations Impacts on Students Learning}
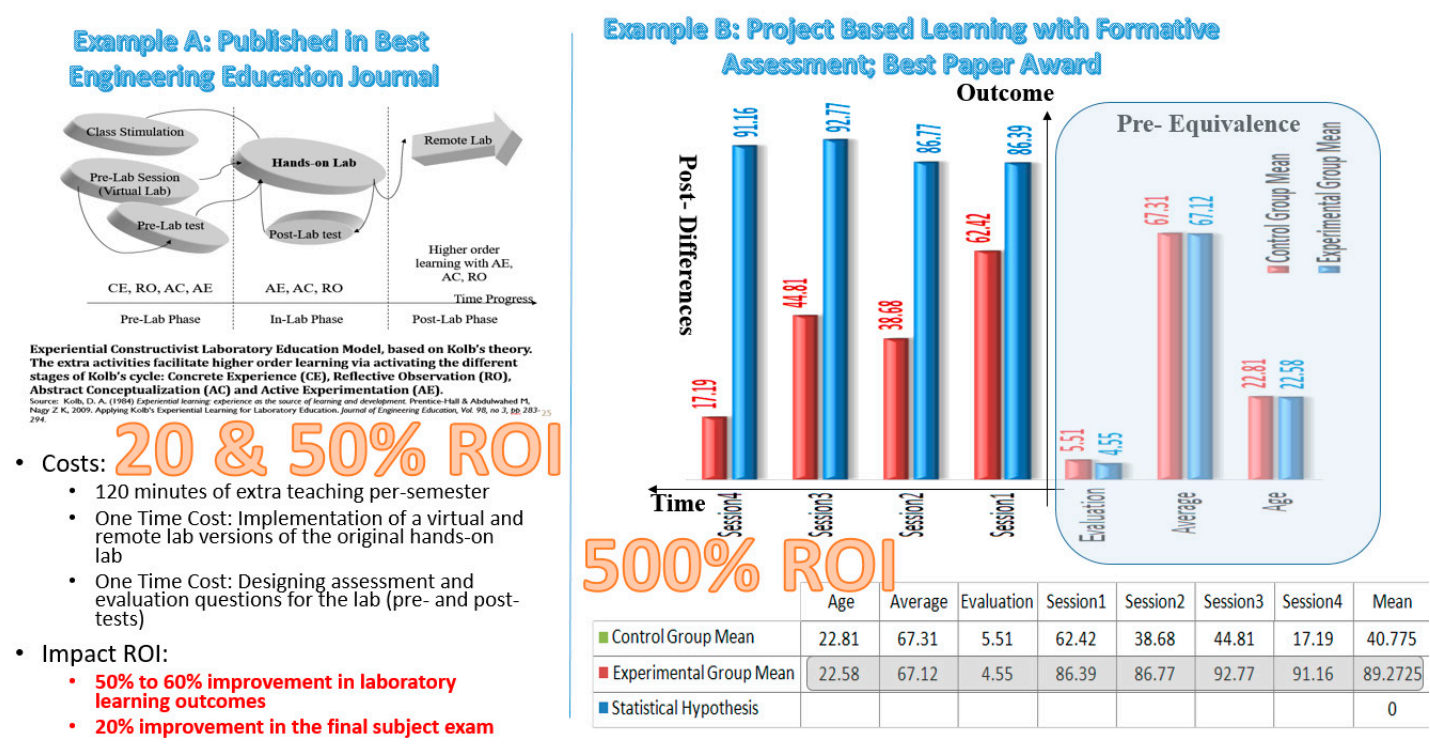

Figure A3. Exemplar cases of engineering education innovation interventions impact on students learning gains; for further details see [32,43]. ROI: return in investment.

\section{Appendix D. Gradual and Progressive Timeline of Department Implementation}

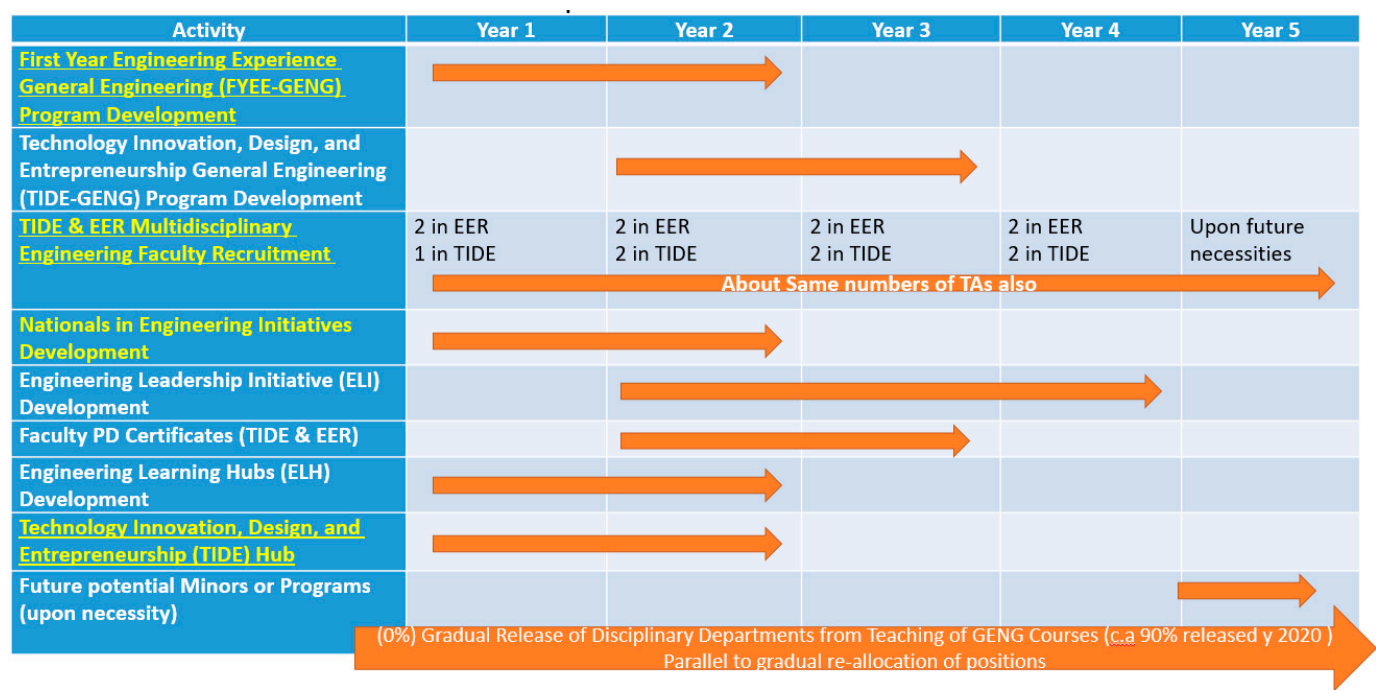

Figure A4. Gradual implementation plan of TIEE department over five years.

\section{References}

1. National Academy of Engineering (NAE). The Engineer of 2020: Visions of Engineering in the New Century; The National Academies Press: Washington, DC, USA, 2004.

2. National Academy of Engineering (NAE). Educating the Engineer of 2020: Adapting Engineering Education to the New Century; The National Academies Press: Washington, DC, USA, 2005.

3. Nuclear Regulatory Commission (NRC). Rising above the Gathering Storm: Energizing and Employing America for a Brighter Economic Future Committee on Prospering in the Global Economy of the 21st Century: An Agenda for American Science and Technology; National Academy Press: Washington, DC, USA, 2007.

4. Pinelli, T.E.; Haynie, W.J. A case for the nationwide inclusion of engineering in the K-12 curriculum via technology education. J. Technol. Educ. 2010, 21, 52-68. [CrossRef] 
5. Luo, J.; Olechowski, A.L.; Magee, C.L. Technology-Based Design as a Strategy for Sustainable Economic Growth. Technovation 2014, 34, 663-677. [CrossRef]

6. Obama's Campaign to Improve the Participation and Performance of America's Students in Science, Technology, Engineering, and Mathematics (STEM). “Educate to Innovate". 2009. Available online: http:/ / www.whitehouse.gov/issues/education/educate-innovate (accessed on 26 June 2011).

7. Borrego, M.; Bernhard, J. The emergence of engineering education research as an internationally connected field of inquiry. J. Eng. Educ. 2011, 100, 14-47. [CrossRef]

8. Abdulwahed, M.; Ghani, S.; Hasna, M.O.; Hamouda, A. Life is engineering program: Impact of an engineering outreach project in K-12. In Proceedings of the 2013 IEEE Global Engineering Education Conference (EDUCON), Berlin, Germany, 13-15 March 2013; pp. 827-833.

9. Melsa, J. Transforming engineering education through educational scholarship. Guest Ed. J. Eng. Educ. 2007, 96, 171-172. [CrossRef]

10. The Steering Committee of the National Engineering Education Research Colloquies. The national engineering education research colloquies (Special Report). J. Eng. Educ. 2006, 95, 257-258.

11. Watson, K. Change in engineering education: Where does research fit? J. Eng. Educ. 2009, 98, 3-4. [CrossRef]

12. Streveler, R.; Smith, K. Guest Editorial: Conducting rigorous research in engineering education. J. Eng. Educ. 2006, 95, 3-105. [CrossRef]

13. Jesiek, B.K.; Borrego, M.; Beddoes, K. Advancing global capacity for engineering education research (AGCEER): Relating research to practice, policy and industry. J. Eng. Educ. 2010, 99, 107-119. [CrossRef]

14. Borrego, M.; Beddoes, K.; Jesiek, B.K. International perspectives on the need for interdisciplinary expertise in engineering education scholarship. In Proceedings of the Australasian Association for Engineering Education Conference, Adelaide, Australia, 6-9 December 2009.

15. White, R.M.; Allen, T.R.; Cunningham, C.M.; Diefes-Dux, H.A.; Godoy-Gonzalez, M.A.; Newberry, P.B.; Rosen, L.P.; James Rutherford, J.; Schunn, C.D.; Clafani, S.K.; et al. Standards for K-12 Engineering Education? National Academy of Engineering: Washington, DC, USA, 2010.

16. CEAS SEE. School of Engineering Education, University of Cincinnati. 2011. Available online: http:/ / see.ceas.uc.edu/ (accessed on 26 June 2011).

17. Mills, J.E.; Treagust, D.F. Engineering Education-Is Problem-Based or Project Based Learning the Answer? Aust. J. Eng. Educ. 2003, 3, 205-207.

18. Litzinger, T.A.; Lattuca, L.R.; Hadgraft, R.G.; Newstetter, W.C. Engineering education and the development of expertise: Learning experiences that support the development of expert engineering practice. J. Eng. Educ. 2011, 100, 123-150. [CrossRef]

19. Yadav, A.; Subedi, D.; Lundeberg, M.A.; Bunting, C.F. Problem-based Learning: Influence on Students' Learning in an Electrical Engineering Course. J. Eng. Educ. 2011, 100, 253-280. [CrossRef]

20. Patil, A.; Codner, G. Accreditation of engineering education: Review, observations and proposal for global accreditation. Eur. J. Eng. Educ. 2007, 32, 639-651. [CrossRef]

21. Abdulwahed, M.; Balid, W.; Hasna, M.O.; Pokharel, S. August. Skills of engineers in knowledge based economies: A comprehensive literature review, and model development. In Proceedings of the 2013 IEEE International Conference on Teaching, Assessment and Learning for Engineering (TALE), Kuta, Indonesia, 26-29 August 2013; pp. 759-765.

22. Hamad, J.A.; Hasanain, M.; Abdulwahed, M.; Al-Ammari, R. Ethics in engineering education: A literature review. In Proceedings of the 2013 IEEE Frontiers in Education Conference (FIE), Oklahoma City, OK, USA, 23-26 October 2013; pp. 1554-1560.

23. Lohmann, J.R.; de Graaff, E. Advancing the global capacity for engineering education research (AGCEER): A year of international dialogue. In Proceedings of the American Society for Engineering Education Annual Conference, Pittsburgh, PA, USA, 22-25 June 2008.

24. Wankat, P.C.; Felder, R.M.; Smith, K.A.; Oreovicz, F.S. The scholarship of teaching and learning in engineering. In Disciplinary Styles in the Scholarship of Teaching and Learning; Huber, M.T., Morreale, S.P., Eds.; American Association for Higher Education and the Carnegie Foundation for the Advancement of Teaching: Menlo Park, CA, USA, 2002; pp. 217-237.

25. Rossiter, J.A.; Gray, L.; Diercks O’Brien, G. A case study in using theory of change to improve teaching practice in a control department. In Proceedings of the International Conference on Engineering Education, (ICEE), Coimbra, Portugal, 3-7 September 2007. 
26. Borrego, M. Development of engineering education as a rigorous discipline: A study of the publication patterns of four coalitions. J. Eng. Educ. 2007, 96, 5-18. [CrossRef]

27. Tryggvason, G.; Apelian, D. Re-Engineering Engineering Education for the Challenges of the 21st Century. JOM 2006, 57, 14-17. [CrossRef]

28. Litzinger, T.A. Engineering education centers and programs: A critical resource. J. Eng. Educ. 2010, 99, 3-4. [CrossRef]

29. The Steering Committee of the National Engineering Education Research Colloquies. The research agenda for the new discipline of engineering education (Special Report). J. Eng. Educ. 2006, 95, 259-261.

30. Jesiek, B.K.; Borrego, M.; Beddoes, K.; Hurtado, M. Internationalizing engineering education research: Mapping countries and keywords to identify new collaborative horizons. In Proceedings of the American Society for Engineering Education Annual Conference, Austin, TX, USA, 14-17 June 2009.

31. Dick, W.; Carey, L.; Carey, J.O. The Systematic Design of Instruction, 5th ed.; Addison, Wesley, Longman: New York, NY, USA, 2001.

32. Abdulwahed, M.; Nagy, Z.K. A Control Systems Engineering Approach to Designing an Effective Lecturing Model: The Implication of Feedback and Self-Construction of Knowledge. Innovations 2012. Available online: http://www.ineer.org/Selections-from-ineer-books/Innovations-2012_Chap-3.pdf (accessed on 15 January 2017).

33. Abdulwahed, M.; Nagy, Z.K.; Blanchard, R.E. Beyond the engineering pedagogy: Engineering the pedagogy, modelling Kolb's learning cycle. In Proceedings of the Nineteenth Annual Conference of the Australian Association for Engineering Education (AaeE 2008), Yeppoon, Australia, 7-10 December 2008.

34. Shaban, K.B.; Abdulwahed, M. Research-based learning in computing courses for senior engineering students. In Proceedings of the 2012 IEEE International Conference on Teaching, Assessment and Learning for Engineering (TALE), Hong Kong, China, 20-23 August 2012.

35. Johri, A.; Olds, B. Situated engineering learning: Bridging engineering education research and the learning sciences. J. Eng. Educ. 2011, 100, 151-185. [CrossRef]

36. Geiger, K. Analyse der Wechselstromtechnik und die Folgerung für Ihre Lehre an Fachschulen; Technischen Hochschule Dresden: Dresden, Germany, 1954. (In German)

37. Melezinek, A. Engineering Pedagogy-Ingenieurpädagogik: Theory and Practice of Technical Teacher Training. In Proceedings of the International Conference on Engineering Education, Oslo, Norway, 6-10 August 2001.

38. Strobel, J.; Evangelou, D.; Streveler, R.; Smith, K. The many homes of engineering education research: Historical analysis of $\mathrm{PhD}$ dissertations. In Presented at the Research in Engineering Education Symposium, Davos, Switzerland, 7-10 July 2008.

39. Rockland, R.; Bloom, D.S.; Carpinelli, J.; Burr-Alexander, L.; Hirsch, L.S.; Kimmel, H. Advancing the "E" in K-12 STEM Education. J. Technol. Stud. 2010, 36, 53-64.

40. Abdulwahed, M.; Hasna, M.O.; Froyd, J. (Eds.) Advances in Engineering Education in the Middle East and North Africa, Current Status and Future Insights; Springer: Cham, Switzerland, 2016; ISBN: 978-3-319-15322-3 (Print); 978-3-319-15323-0 (Online).

41. Rogers, E.M. Diffusion of Innovations; Simon and Schuster: New York, NY, USA, 2010.

42. Christensen, C.M.; Overdorf, M. Meeting the challenge of disruptive change. Harv. Bus. Rev. 2000, 78, 66-77.

43. Abdulwahed, M.; Balid, B. An assessment rich PBL vs. classical teaching approach. In Presented at the 2nd International Research Symposium on PBL (IRSPBL09), Melbourne, Australia, 2-4 December 2009.

44. Abdulwahed, M.; Hasna, M.O. Engineering and Technology Talent for Innovation and Knowledge Based Economies: Competencies, Leadership, and Roadmap for Implementation; Springer: Cham, Switzerland, 2017; ISBN: 978-3-319-46439-8.

(C) 2017 by the author; licensee MDPI, Basel, Switzerland. This article is an open access article distributed under the terms and conditions of the Creative Commons Attribution (CC BY) license (http:/ / creativecommons.org/licenses/by/4.0/). 